\title{
Critical Period of Weed Control in Snap Bean on Organic Soils in South Florida
}

\author{
Dennis C. Odero ${ }^{1}$ \\ Everglades Research and Education Center, University of Florida-IFAS, \\ 3200 E Palm Beach Road, Belle Glade, FL 33430
}

\author{
Alan L. Wright \\ Indian River Research and Education Center, University of Florida-IFAS, \\ 2199 South Rock Road, Fort Pierce, FL 34945
}

Additional index words. Phaseolus vulgaris duration of interference, duration of weed-free period, critical timing of weed removal, critical weed-free period, weed interference, yield loss

Abstract. Field studies were conducted in 2011 and 2012 in Belle Glade, FL, to evaluate the critical period of weed control (CPWC) in snap bean grown on organic soils in the Everglades Agricultural Area (EAA) of South Florida. Treatments consisting of increasing duration of weed interference and weed-free period were imposed at weekly intervals from 0 to 7 weeks after emergence (WAE) of snap bean. The beginning and end of the CPWC based on $2.5 \%, 5 \%$, and $10 \%$ snap bean acceptable yield loss (AYL) levels were determined by fitting log-logistic and Gompertz models to represent increasing duration of weed interference and weed-free period, respectively. Based on $2.5 \%$ yield loss, the CPWC was 7.2 weeks long, beginning 1.2 (cotyledon and unifoliate leaf) and ending 8.4 WAE (mid-pod set, $50 \%$ of pods reached maximum length). At $5 \%$ yield loss, the CPWC was 5.0 weeks, beginning 1.7 (first to second trifoliate leaf) and ending 6.7 WAE (mid-flower to early pod set, $50 \%$ of flowers open and one pod reached maximum length). At 10\% yield loss, the CPWC was 3.0 weeks, beginning 2.2 (second trifoliate leaf) and ending 5.2 WAE (early flowering, one open flower). Based on these results, the beginning of CPWC was hastened, whereas the end was delayed at different yield loss levels showing that acceptable weed control in snap bean on organic soils in the EAA is required throughout much of the growing season to minimize yield loss.

Snap bean (Phaseolus vulgaris L.) is an important crop cultivated in the EAA of south Florida for the processing market. The EAA is dominated by organic soils (histosols) with up to $85 \%$ organic matter underlain by limestone bedrock (Snyder, 1994). Weed interference is the major limiting factor to profitable snap bean production in the EAA. Snap bean is a short-season $(\approx 60 \mathrm{~d})$ crop and very sensitive to weed interference. Several studies have documented yield losses in snap bean and similar species of up to $77 \%$ from weed interference depending on weed species composition and density (Aguyoh and Masiunas, 2003a, 2003b; Blackshaw, 1991; Evanylo and Zehnder, 1989; Neary and Majek, 1990; Ugen et al., 2002; William and Warren, 1975). Growers in the EAA typically rely on preemergence application of $S$-metolachlor to provide early-season weed control followed by postemergence application of bentazon for broadleaf weed

\footnotetext{
Received for publication 25 Sept. 2017. Accepted for publication 5 Feb. 2018

We thank Nikol Havranek and the staff at the Everglades Research and Education Center for their assistance with establishing, maintaining, and harvesting experimental plots.

${ }^{1}$ Corresponding author. E-mail: dcodero@ufl.edu.
}

control in combination with sethoxydim for grass control. However, these herbicides do not provide acceptable control of problematic weeds, most notably common lambsquarters (Chenopodium album L.), resulting in need for mechanical cultivation between row middles to supplement chemical weed control. Correct timing of weed control measures in snap bean is important to optimize yield, given the crop's short growth cycle. Therefore, determination of the CPWC in snap bean on organic soils in the EAA can help improve timing of weed control measures to minimize yield loss from weed interference.

The CPWC is the time interval in the crop's growth cycle during which weed control measures must be undertaken to prevent yield loss (Zimdahl, 2004). It is described by the time interval between two separately measured crop-weed interference components, namely, the critical timing of weed removal (CTWR) or the maximum amount of early-season weed interference that the crop can tolerate before it suffers irrevocable yield loss, and the critical weedfree period (CWFP) or the minimum weedfree period required from the time of planting to prevent unacceptable yield loss (Knezevic et al., 2002). The CTWR and CWFP analogous to duration of weed interference and weed-free period are used to determine the beginning and end of the CPWC, respectively, based on an AYL level a grower is willing to take depending on the cost of weed control and anticipated financial gain (Knezevic et al., 2002). Several factors such as environmental conditions, crop genetics, and cultural practices may influence the CPWC by affecting weed species composition, weed density, time of weed emergence relative to the crop, and crop-weed growth (Norsworthy and Oliveira, 2004). Therefore, understanding and determining the CPWC provides a basis for planning effective weed control strategies in crops (Knezevic et al., 2002; Swanton and Weise, 1991; Van Acker et al., 1993).

Several studies have focused on evaluating the effects of duration of interference of single weed species on snap bean and similar species. Mirshekari et al. (2010) estimated the critical period of redroot pigweed (Amaranthus retroflexus L.) control to be 6.6 and 5.1 weeks after snap bean emergence at $5 \%$ and $10 \%$ yield loss level, respectively. Blackshaw (1991) reported that hairy nightshade (Solanum physalifolium Rusby) interference within the first 3 weeks after crop emergence was sufficient to reduce dry bean yield. The critical duration of interference of common cocklebur (Xanthium strumarium L.) emerging with snap bean was between emergence and full bloom stage of snap bean (Neary and Majek, 1990). William and Warren (1975) reported that the critical period of purple nutsedge (Cyperus rotundus L.) interference occurred at $\approx 4$ weeks for snap bean. However, most cultivated fields have mixed weed populations with no monoculture of single weed species making determination of CPWC based on mixed weed populations important in cropping systems. Currently, no information is available on the effect of mixed weed populations on the CPWC in snap bean grown on organic soils in the EAA. Therefore, the objective of this study was to determine the beginning and end of CPWC in snap bean under natural field conditions on organic soils in the EAA to enable optimization of weed control timing.

\section{Materials and Methods}

Field experiments were conducted at the University of Florida Everglades Research and Education Center (EREC) in Belle Glade, FL, in 2011 (lat. $26^{\circ} 39^{\prime} 37.8^{\prime \prime} \mathrm{N}$, long. $80^{\circ} 37^{\prime} 31.6^{\prime \prime} \mathrm{W}$ ) and 2012 (lat. $26^{\circ} 39^{\prime} 38.0^{\prime \prime} \mathrm{N}$, long. 80³7'29.6"W). The soil type was Dania Muck (Euic, hyperthermic, shallow Lithic Haplosaprists) with a $\mathrm{pH}$ of 7.3 and $80 \%$ organic matter. Experimental fields were prepared by chisel plowing followed by disking with a harrow before planting both years. Snap bean 'Prevail' was planted on 16 Sept. 2011 and 9 Mar. 2012 at a seeding rate of 247,000 seeds/ha. 'Prevail' was chosen because it is one of the major cultivars grown in the EAA. No fertilizer was applied at planting or later in the season, a common practice associated with snap bean production on high organic matter soils in the EAA. 
Snap bean and weeds both emerged within 5$7 \mathrm{~d}$ after planting both years. Both average daily air and soil temperatures during the duration of the study were 23 and $22{ }^{\circ} \mathrm{C}$ in 2011 and 2012, respectively. Average daily total solar radiation for the duration of the study was 14 and $17 \mathrm{MJ} \cdot \mathrm{m}^{-2}$ in 2011 and 2012, respectively, whereas a total of $368 \mathrm{~mm}$ of rainfall was received in 2011 compared with $115 \mathrm{~mm}$ in 2012 for the entire duration of the study. Weather data were collected from the EREC weather station (http://erec.ifas.ufl.edu/WD/Ewdmain.htm). Water was applied by subsurface irrigation from field ditches by maintaining a water table $61 \mathrm{~cm}$ below the soil surface both years to ensure that water was not a limiting factor (Snyder et al., 1978). Individual plots were established immediately after snap bean emergence. Experimental plots consisted of four snap bean rows $6.1-\mathrm{m}$ long and spaced $76-\mathrm{cm}$ apart arranged in a randomized complete block design with four replications both years.

Naturally occurring weed populations (Table 1) were used to determine appropriate duration of weed interference and weed-free period treatments. Two sets of treatments were imposed to represent both increasing duration of weed interference and weed-free period. Weeds were allowed to emerge and compete with snap bean for $1,2,3,4,5,6$, and 7 weeks after emergence (WAE) for the increasing duration of weed interference, and then plots were kept weed free for the remainder of the season. For the duration of weed-free period, plots were kept weed free for $1,2,3,4,5,6$, and 7 WAE, after which the weeds were allowed to re-infest and compete with snap bean for the remainder of the season. In addition, season-long weedy and weed-free controls were included. The plots were kept weed free by hand removal and hoeing throughout the season. These included the weed-free controls and treatments that were to be kept weed free early before allowing weed interference or weed free after varying lengths of weed interference. Growth stage of snap bean was determined at each weed removal timing (Brick and Johnson, 2004). Aboveground weed biomass was harvested from $0.2 \mathrm{~m}^{2}$ per plot in the duration of interference experiments before each weed removal period. Harvested weeds were dried at $80{ }^{\circ} \mathrm{C}$ for $72 \mathrm{~h}$ and weighed to determine aboveground dry biomass. Snap bean was harvested by hand from the two middle rows of each plot at the optimum edible maturity stage to determine the yield on 18 Nov. 2011 and 11 May 2012.

Statistical analysis. Relative yield of individual plots were calculated as a percentage of the corresponding weed-free yield. Analysis of variance was conducted on relative yield to determine whether the effect of increasing duration of weed interference and weed-free period were significant $(P=$ 0.05) using $\mathrm{R}$ ( $\mathrm{R}$ version 3.4.1; R Development Core Team, 2017). No significant interactions with year were observed for each component of CPWC; therefore, data were combined over years for analysis. Nonlinear regression analysis was used to estimate the relative yield of snap bean as a function of increasing duration of weed interference and weed-free period. A four-parameter $\log$ logistic equation was fitted to assess the effect of increasing duration of interference on snap bean relative yield and to determine the beginning of the CPWC:

$$
Y=[c+(d-c)] /\{1+\exp [b(\log T-\log e)]\},
$$

where $Y$ is the relative yield (\% of seasonlong weed-free yield), $T$ is the time expressed as WAE, $b$ is the slope at the inflection point, $c$ is the lower limit or the minimum relative yield in the presence of weed interference, $d$ is the upper limit or the maximum relative yield in the absence of weed interference, and $e$ is the number of WAE where the inflection point occurs. The three-parameter Gompertz model was used to describe the effect of increasing duration of weed-free period on snap bean relative yield and to determine the end of CPWC:

$$
Y=d(\exp \{-\exp [b(\log T-\log e)]\}),
$$

where $Y$ is the relative yield (\% of seasonlong weed-free yield), $T$ is the time expressed as WAE, $b$ is the slope at the inflection point, $d$ is the maximum relative yield in the absence of weed interference, and $e$ is the number of WAE where the inflection point occurs. Analysis of variance was conducted on weed biomass data to determine the effect of duration of interference. Weed biomass data were combined over years because of no significant year effect. Weed biomass response to the duration of interference was modeled using Eq. [1], where $Y$ is the weed biomass $\left(\mathrm{g} \cdot \mathrm{m}^{-2}\right), b$ is the relative slope at the inflection point, $c$ is the minimum weed

Table 1. Weed density and species present after snap bean emergence on organic soil in 2011 and 2012 in Belle Glade, FL.

\begin{tabular}{lcc}
\hline & \multicolumn{2}{c}{ Weed density (plants $/ \mathrm{m}^{2}$ ) } \\
\cline { 2 - 3 } Weed species & 2011 & 2012 \\
\hline Common lambsquarters (Chenopodium album L.) & 26 & 31 \\
Spiny amaranth (Amaranthus hybridus L.) & 48 & 19 \\
Common purslane (Portulaca oleracea L.) & 6 & 52 \\
Goosegrass [Eleusine indica (L.) Gaertn.] & 19 & 16 \\
Fall panicum (Panicum dichotomiflorum Michx.) & 4 & 3 \\
Common ragweed (Ambrosia artemisiifolia L.) & 1 & 1 \\
Yellow nutsedge (Cyperus esculentus L.) & 4 & 5 \\
Spreading dayflower (Commelina diffusa Burm. f.) & 1 & 1 \\
\hline
\end{tabular}

Table 2. Parameter estimates (SE in parenthesis) for snap bean relative yield on organic soil combined over 2011 and 2012 in Belle Glade, FL, using log-logistic and Gompertz models characterizing the duration of weed interference and weed-free period, respectively. ${ }^{\mathrm{z}}$

\begin{tabular}{lcccc}
\hline & \multicolumn{4}{c}{ Parameter estimates $( \pm \mathrm{SE})$} \\
\cline { 2 - 5 } Model & $b$ & $c$ & $d$ & $e$ \\
\hline Log-logistic & $3.62(0.97)$ & $17.33(8.73)$ & $98.70(3.35)$ & $3.94(0.34)$ \\
Gompertz & $-0.54(0.09)$ & - & $99.18(4.13)$ & $0.85(0.16)$ \\
\hline
\end{tabular}

${ }^{\mathrm{z}} \log$-logistic: $Y=[c+(d-c)] /\{1+\exp [b(\log T-\log e)]\}$, where $Y$ is relative yield $(\%$ of season-long weed-free), $T$ is the time expressed as weeks after emergence (WAE), $b$ is the slope at the inflection point, $c$ is the lower limit or the minimum relative yield in the presence of weed interference, $d$ is upper limit or the maximum relative yield in the absence of weed interference, and $e$ is the number of WAE where the inflection point occurs. Gompertz: $Y=d(\exp \{-\exp [b(\log T-\log e)]\})$, where $Y$ is relative yield $(\%$ of season-long weed-free), $T$ is time expressed as WAE, $b$ is the slope at the inflection point, $d$ is the maximum relative yield in the absence of weed interference, and $e$ is the number of WAE where the inflection point occurs. 
CPWC in several crops (Evans et al., 2003; Everman et al., 2008; Knezevic et al., 2002; Norsworthy and Oliveira, 2004; Odero and Wright, 2013; Smitchger et al., 2012; Webster et al., 2007; Williams, 2006). Determination of the AYL level depends on the cost of weed management in relation to the yield benefit achieved by the grower. The CPWC in snap bean averaged over 2011 and 2012 was estimated to be 7.2, 5.0, and 3.0 WAE at $2.5 \%, 5 \%$, and $10 \%$ yield loss level, respectively, on organic soils in the EAA. Because timing of herbicide application and tillage are based on the stage of crop development and susceptible stages of weed growth (Weaver, 1984), snap bean growth stages corresponding to different WAE were also used to describe the beginning and end of CPWC (Table 3).

The beginning of the CPWC in snap bean was estimated to be 1.2, 1.7, and 2.2 WAE which corresponded to the cotyledon and unifoliate leaf, first to second trifoliate leaf and second trifoliate leaf stages of snap bean at $2.5 \%, 5 \%$, and $10 \%$ yield loss levels, respectively (Table 3). Ngouajio et al. (1997) reported that the beginning of CPWC occurred between dry bean emergence and the second trifoliate leaf. Similarly, Woolley et al. (1993) reported the beginning of CPWC in white bean to correspond to the second trifoliate leaf. Burnside et al. (1998) reported that the beginning of CPWC in dry bean was 3 weeks after planting. Dawson (1964) showed that the first 5-7 weeks after planting dry bean were the most critical for weed control. The onset of yield loss was early for snap bean under the EAA growing conditions characterized by high organic matter soils. Predominant weed species especially common lambsquarters and spiny amaranth had prolific growth and development. Amaranthus species and common lambsquarters have been reported to result in up to $100 \%$ yield loss in several crops following season-long interference (Aguyoh and Masiunas, 2003b; Berry et al., 2006; Fischer et al., 2004; Massinga et al., 2001; Meyers et al., 2010). Our results show that snap bean is very vulnerable to weed interference from the early stages of its growth in the EAA. Early-season weed interference is very important from weeds that emerge with the crop (Hock et al., 2006). Based on these results, snap bean growers in the EAA should use preemergence herbicides with enough soil residual activity to control weeds long enough before the crop can tolerate postemergence herbicide application or mechanical cultivation between the rows. Bentazon, the most commonly used postemergence herbicide can only be applied when snap bean have at least one to two fully expanded trifoliate leaves (Anonymous, 2017), which is within the period when weed removal is critical.

The end of the CPWC in snap bean was 8.4, 6.7, and 5.2 WAE which corresponded to the mid-pod set until harvesting ( $50 \%$ of pods reached maximum length), mid-flower to early pod set $(50 \%$ of flowers open and one pod reached maximum length), and early flowering (one open flower) stages of snap bean at $2.5 \%, 5 \%$, and $10 \%$ yield loss levels, respectively (Table 3). Woolley et al. (1993) reported the end of CPWC in white bean to be about at the mid-flower growth stage. William and Warren (1975) reported the CWFP in snap bean between 3 and 5 weeks after planting from purple nutsedge interference. Overall, the end of the CPWC was delayed depending on the yield loss level. To prevent $2.5 \%$ and $5 \%$ yield loss in snap bean, weed control is required through flowering, pod formation, and maturation, indicating that snap bean is not very competitive with weeds in the high organic matter soils of the EAA. This implies that preemergence and postemergence herbicides used in snap bean should provide weed control throughout the season. However, in situations where these herbicides do not provide needed residual activity, mechanical cultivation can be used to supplement chemical weed control.
The log-logistic [Eq. (1)] model provided the best fit to estimate weed biomass accumulation in response to increasing duration of weed interference. A test of lack-of-fit at the $95 \%$ level was not significant for the curve $(P>0.05)$, indicating that the regression model was appropriate (Ritz and Streibig, 2005). Weed biomass increased as the duration of weed interference increased (Fig. 2). The beginning of the CPWC at the different yield loss levels corresponded with the period of the most dramatic increase in weed biomass. Weed biomass increased $92 \%$ from 1 (snap bean cotyledon and unifoliate leaf stage) to 2 (snap bean first and second trifoliate leaf stages) WAE. By 5 WAE or the fifth trifoliate leaf, weeds had accumulated $50 \%$ of the maximum biomass attained at the end of the season. Maximum biomass in the absence of weed removal was estimated to be $1120 \mathrm{~g} \cdot \mathrm{m}^{-2}$. Weed biomass increased substantially until the end of the season.

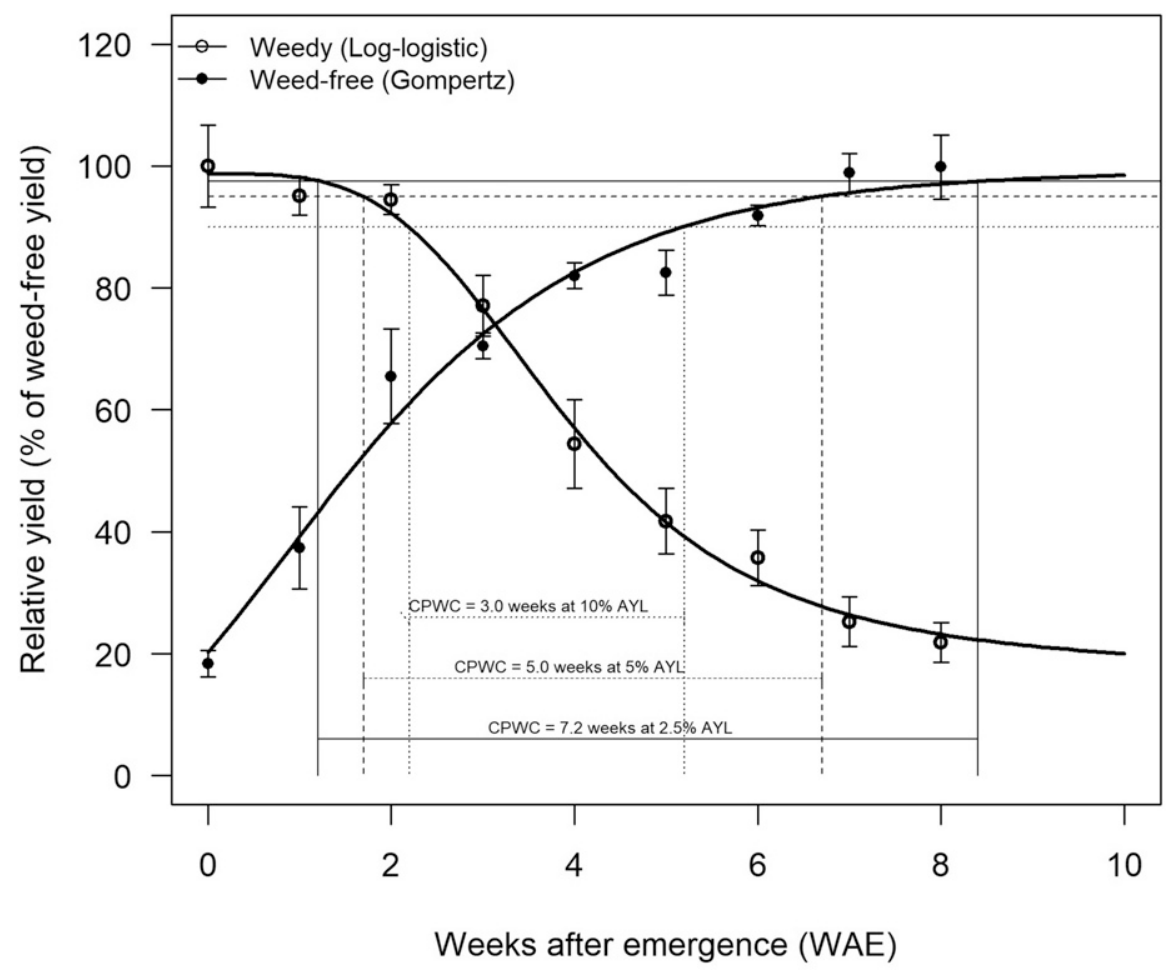

Fig. 1. Snap bean relative yield on organic soil as a function of the duration of weed interference $(O)$ and weed-free period (•) combined over 2011 and 2012 in Belle Glade, FL. Eq. [1] (log-logistic model) and [2] (Gompertz model) were used to predict the beginning and end of the critical period of weed control (CPWC), respectively, at 2.5\%, 5\%, and 10\% snap bean acceptable yield loss (AYL) levels. Parameter estimates are listed in Table 2.

Table 3. The critical period of weed control (CPWC) in snap bean on organic soil combined over 2011 and 2012 in Belle Glade, FL, for three acceptable yield loss (AYL) levels expressed as weeks after emergence (WAE) and the corresponding crop growth stage (CGS).

\begin{tabular}{|c|c|c|c|c|c|c|}
\hline \multirow[b]{3}{*}{ Component $^{z}$} & \multicolumn{3}{|c|}{ WAE } & \multicolumn{3}{|c|}{$\mathrm{CGS}^{\mathrm{y}}$} \\
\hline & 2.5 & 5 & 10 & 2.5 & 5 & 10 \\
\hline & & & & & & \\
\hline Beginning of CPWC & 1.2 & 1.7 & 2.2 & $\mathrm{VC}$ & $\mathrm{V} 1-\mathrm{V} 2$ & $\mathrm{~V} 2$ \\
\hline End of CPWC & 8.4 & 6.7 & 5.2 & R4 & $\mathrm{R} 2-\mathrm{R} 3$ & $\mathrm{R} 1$ \\
\hline
\end{tabular}

${ }^{\mathrm{Z}}$ Parameters determined from fitting the log-logistic [Eq. (1)] and Gompertz [Eq. (2)] models were used to estimate WAE indicating the beginning and end of the CPWC, respectively.

${ }^{\mathrm{y}} \mathrm{CGS}$ : VC = cotyledon and unifoliate leaf; V1 = first trifoliate leaf; V2 = second trifoliate leaf; R1 = early flower (one open flower); $\mathrm{R} 2=$ mid-flower $(50 \%$ open flowers); $\mathrm{R} 3$ = early pod set (one pod has reached maximum length); R4 = mid-pod set (50\% of pods have reached maximum length) (Brick and Johnson, 2004). 


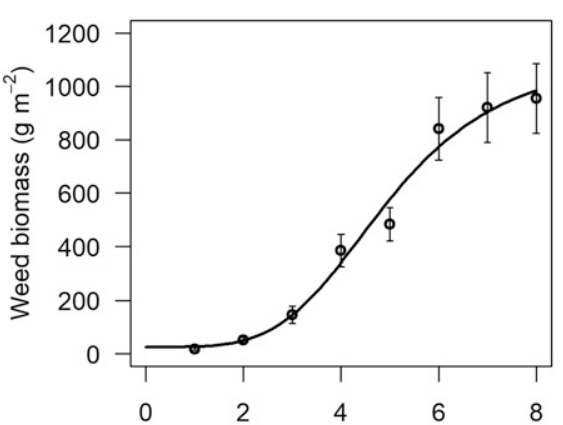

Weeks after emergence (WAE)

Fig. 2. Aboveground dry weed biomass in response to increasing duration of interference in snap bean on organic soil expressed as weeks after emergence combined over 2011 and 2012 in Belle Glade, FL. Eq. [1] $\{Y=c+(d-c) / 1+\exp$ [b $(\log T-\log e)]\}$ was used to predict weed biomass response, where $Y$ is the weed biomass $\left(\mathrm{g} \cdot \mathrm{m}^{-2}\right), b$ is the relative slope at the inflection point, $c$ is the minimum weed biomass, $d$ is the maximum weed biomass, and $e$ is the inflection point. Parameter estimates (SE in parenthesis) were $b=-4.12(1.65), c=25.34(70.01), d=$ 1120.35 (212.08), and $e=4.98$ (0.58).

However, the increase gradually declined toward the end of the season.

Our results show that the CPWC for snap bean grown on organic soils in the EAA necessary to avoid $2.5 \%$ yield loss was between 1.2 (cotyledon and unifoliate leaf) and 8.4 WAE or until harvesting (mid-pod set, $50 \%$ of pods reached maximum length). At $5 \%$ yield loss, the CPWC was between 1.7 (first to second trifoliate leaf) and 6.7 WAE (mid-flower to early pod set, $50 \%$ of flowers open and one pod reached maximum length). At $10 \%$ yield loss, the CPWC was between 2.2 (second trifoliate leaf) and 5.2 WAE (early flowering, one open flower). These intervals show that weed control in snap bean is required throughout most of the growing season to maximize yield and minimize the effect of weed interference. Therefore, weed control using residual preemergence in combination with postemergence herbicides or tillage in snap bean should be used to provide weed control throughout most of the season to prevent unacceptable yield loss on organic soils in the EAA.

\section{Literature Cited}

Aguyoh, J.N. and J.B. Masiunas. 2003a. Interference of large crabgrass (Digitaria sanguinalis) with snap beans. Weed Sci. 51:171-176.

Aguyoh, J.N. and J.B. Masiunas. 2003b. Interference of redroot pigweed (Amaranthus retroflexus) with snap beans. Weed Sci. 51:202-207.
Anonymous. 2017. Basagran ${ }^{\circledR}$ herbicide. Winfield United. 20 Sept. 2017. < https://www.winfieldunited. com/Product/Herbicides-Insecticides-Fungicides $>$.

Berry, A.D., W.M. Stall, B. Rathinasabapathi, G.E. Macdonald, and R. Charudattan. 2006. Smooth pigweed (Amaranthus hybridus L.) and livid amaranth (Amaranthus lividus) interference with cucumber (Cucumis sativus). Weed Technol. 20:227-231.

Blackshaw, R.E. 1991. Hairy nightshade (Solanum sarrachoides) interference in dry beans (Phaseolus vulgaris). Weed Sci. 39:48-53.

Brick, M.A. and J.J. Johnson. 2004. Classification, development and varietal performance, p. 713. In: H.F. Schwartz and M.A. Brick (eds.). Dry bean production and integrated pest management. 2nd ed., Bulletin 562A. Regional Publication Produced by: Colorado State University, University of Nebraska, University of Wyoming.

Burnside, O.C., M.J. Wiens, B.J. Holder, S. Weisberg, E.A. Ristau, M.M. Johnson, and J.H. Cameron. 1998. Critical periods for weed control in dry beans (Phaseolus vulgaris). Weed Sci. 46:301-306.

Dawson, J.J. 1964. Competition between irrigated field beans and annual weeds. Weeds 12:206208.

Evans, S.P., S.Z. Knezevic, J.L. Lindquist, C.A. Shapiro, and E.E. Blankenship. 2003. Nitrogen application influences the critical period for weed control in corn. Weed Sci. 51:408-417.

Evanylo, G.K. and G.W. Zehnder. 1989. Common ragweed interference in snap beans at various soil potassium levels. Appl. Agr. Res. 4:101105.

Everman, W.J., S.B. Clewis, W.E. Thomas, I.C. Burke, and J.W. Wilcut. 2008. Critical period of weed interference in peanut. Weed Technol. 22:63-67.

Fischer, D.W., R.G. Harvey, T.T. Bauman, S. Phillips, S.E. Hart, G.A. Johnson, J.J. Kells, P. Westra, and J. Lindquist. 2004. Common lambsquarters (Chenopodium album) interference with corn across the northcentral United States. Weed Sci. 52:1034-1038.

Hock, S.M., S.Z. Knezevic, A.R. Martin, and J.L. Lindquist. 2006. Soybean row spacing and weed emergence time influence weed competitiveness and competitive indices. Weed Sci. 54:38-46.

Knezevic, S.Z., S.P. Evans, R.C. Van Acker, and J.L. Lindquist. 2002. Critical period for weed control: The concept and data analysis. Weed Sci. 50:773-786.

Massinga, R.A., R.S. Currie, M.J. Horak, and J. Boyer. 2001. Interference of palmer amaranth in corn. Weed Sci. 49:202-208.

Meyers, S.L., K.M. Jennings, J.R. Schultheis, and D.W. Monks. 2010. Interference of palmer amaranth (Amaranthus palmeri) in sweetpotato. Weed Sci. 58:199-203.

Mirshekari, B., A. Javanshir, and H.K. Arbat. 2010. Interference of redroot pigweed (Amaranthus retroflexus) in green bean (Phaseolus vulgaris). Weed Biol. Mgt. 10:120-125.

Neary, P.E. and B.A. Majek. 1990. Common cocklebur (Xanthium strumarium) interference in snap beans (Phaseolus vulgaris). Weed Technol. 4:743-748.

Ngouajio, M., J. Foko, and D. Fouejio. 1997. The critical period of weed control in common bean (Phaseolus vulgaris L.) in Cameroon. Crop Protection 16:127-133.

Norsworthy, J.K. and M.J. Oliveira. 2004. Comparison of the critical period for weed control in wide- and narrow-row corn. Weed Sci. 52:802807.

Odero, D.C. and A.L. Wright. 2013. Phosphorus application influences the critical period of weed control in lettuce. Weed Sci. 61:410 414.

R Development Core Team. 2017. R: A language and environment for statistical computing. R Foundation for Statistical Computing, Vienna, Austria. 3 Nov. 2017.<https://www.R-project.org/>.

Ritz, C. and J.C. Streibig. 2005. Bioassay analysis using R. J. Stat. Softw. 12:1-22.

Smitchger, J.A., I.C. Burke, and J.P. Yenish. 2012. The critical period of weed control in lentil (Lens culinaris) in the Pacific Northwest. Weed Sci. 60:81-85.

Snyder, G.H. 1994. Soils of the EAA, p. 27-41. In: A.B. Bottcher and F.T. Izuno (eds.). Everglades agricultural area (EAA): Water, soil, crop, and environmental management. Univ. Press Florida, Gainesville, FL.

Snyder, G.H., H.W. Burdine, J.R. Crockett, G.J. Gascho, D.S. Harrison, G. Kidder, J.W. Milshoe, D.L. Myhre, F.M. Pate, and S.F. Shih. 1978. Water table management for organic soil conservation and crop production in the Florida Everglades. Univ. Florida Bul. 801:13-14.

Swanton, C.J. and S.F. Weise. 1991. Integrated weed management: The rationale and approach. Weed Technol. 5:657-663.

Ugen, M.A., H.C. Wien, and C.S. Wortmann. 2002. Dry bean competitiveness with annual weeds as affected by soil nutrient availability. Weed Sci. 50:530-535.

Van Acker, R.C., C.J. Swanton, and S.F. Weise. 1993. The critical period of weed control in soybean [Glycine $\max (\mathrm{L}$.$) Mer.]. Weed Sci.$ 41:194-200.

Weaver, S.E. 1984. Critical period of weed competition in three vegetable crops in relation to management practices. Weed Res. 24:317325 .

Webster, T.M., W.H. Faircloth, J.T. Flanders, E.P. Prostko, and T.L. Grey. 2007. The critical period of Bengal dayflower (Commelina bengalensis) control in peanut. Weed Sci. 55:359364.

Williams, M.M. 2006. Planting date influences critical period of weed control in sweet corn. Weed Sci. 54:928-933.

William, R.D. and G.F. Warren. 1975. Competition between purple nutsedge and vegetables. Weed Sci. 23:317-323.

Woolley, B.L., T.E. Michaels, M.R. Hall, and C.J. Swanton. 1993. The critical period of weed control in white bean (Phaseolus vulgaris). Weed Sci. 41:180-184.

Zimdahl, R.L. 2004. Weed-crop competition: A review. 2nd ed. Blackwell, San Diego, CA. 